\title{
PEMBERDAYAAN MASYARAKAT PESISIR DENGAN INOVASI BUDIDAYA UDANG VANAMI MENGGUNAKAN KOLAM TERPAL BERBASIS BAMBU
}

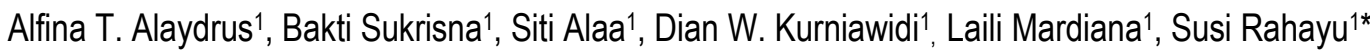 \\ 1Program Studi Fisika/Fakultas Matematika dan IImu Pengetahuan Alam Universitas Mataram \\ ${ }^{*}$ Co-Author : susirahayu@unram.ac.id
}

\begin{abstract}
ABSTRAK. Kemiskinan merupakan permasalahan utama masyarakat wilayah pesisir. Padahal, lingkungan tempat tinggal yang dekat dengan laut memiliki potensi budidaya aneka jenis ikan dan hewan laut lainnya salah satunya udang. Kendala utama pada budidaya udang secara intensif adalah tingginya biaya yang diperlukan untuk pembuatan tambak. Untuk itu, pada kegiatan ini akan dilakukan budidaya udang vanami menggunakan inovasi tambak udang menggunakan teknologi bioflok berbasis kerangka bambu. Inovasi ini diharapkan dapat mereduksi biaya pemeliharaan kolam bioflok berbasis besi yang sudah dikembangkan sebelumnya. Kolam bioflok dibuat dengan diameter 5 meter dengan pengikat tali nilon. Tiang bambu dibuat dengan jarak 3-5 cm. Setiap bambu dijahit dengan tali nilon untuk meningkatkan kekuatan kerangka dari gaya dorong air. Kolam terpal berbasis bambu sudah dapat digunakan oleh masyarakat pesisir sebagai alternative pengganti kolam terpal kerangka besi. Keuntungan pengembangan inovasi kolam ini yaitu tidak perlu perawatan tiap tahun seperti hal nya kolam terpal berbasis besi. Sehingga dapat mengurangi baiaya pemeliharaan setiap tahun.
\end{abstract}

Kata Kunci: Masyarakat Pesisir, Udang Vanami, Kolam Bambu

ABSTRACT. Poverty is the main problem of coastal communities. In fact, the neighborhood living close to the sea has the potential to cultivate various types of fish and other marine animals such as shrimp. The main obstacles in intensive shrimp cultivation are the high cost required for the manufacture of ponds. To that end, in this activity will be cultivated Vanami shrimp cultivation using the innovation of shrimp farms using Bioflok-based technology of bamboo frameworks. This innovation is expected to reduce the maintenance costs of iron-based Bioflok ponds that have been developed previously. The Bioflok pond is made with a diameter of 5 meters with nylon strap straps. Bamboo poles are made with a distance of $3-5 \mathrm{~cm}$. Each bamboo is stitched with nylon rope to increase the skeleton strength of the water push style. Bamboo-based tarp ponds can already be used by coastal communities as an alternative substitute for pond iron frame. The advantages of innovation development of this pond is no need to care every year as it is an iron based trap pond. So it can reduce the maintenance cost every year.

Keyword: Coastal Communities, Vanami Shrimp, Bamboo Pool

\section{PENDAHULUAN}

Potensi alam wilayah pesisir pantai sangat beragam antara lain sektor perikanan, peternakan, pertanian, dan pariwisata. Sektor-sektor tersebut jika dikembangkan secara tepat dapat meningkatkan pertumbuhan ekonomi masyarakat. Sehingga akan berdampak pada peningkatan kesejahteraan masyarakat desa. Salah satu sektor yang menjadi program prioritas pemerintah daerah saat ini yaitu sektor pariwisata.

Pengembangan sektor pariwisata perlu adanya dukungan dari sektor-sektor lain. Salah satunya sektor perikanan. Melalui sektor perikanan, pengembangan difokuskan pada budidaya hewan laut seperti udang. Budidaya udang sangat penting dilakukan karena permintaan pasar yang terus meningkat. Budidaya udang yang sudah banyak dilakukan saat ini menggunakan metode konvensional. Metode konvensional memiliki banyak kelemahan diantaranya limbah udang dapat 
mencemari lingkungan, biaya operasional yang relatif tinggi, dan sering terjadi penebaran penyakit (Supono, 2017). Ketiga faktor resiko ini dapat dikurangi dengan memanfaatkan teknologi bioflok menggunakan kolam terpal ( Amir, 2018). Adapun teknologi bioflok ini dapat menghemat penggunaan air dengan mengkonversi limbah menjadi pakan tambahan. Sehingga berdampak pada efisiensi penggunaan pakan (Amin, 2016 ; Amin et al, 2017).

Aplikasi teknologi bioflok udang vanami yang telah dikembangkan menggunakan besi wire mesh diameter $8 \mathrm{~mm}$ sebagai kerangka kolam terpal (Amir, 2018). Namun, kerangka besi ini memiliki kekurangan yaitu mudah terkorosi sehingga membutuhkan pemeliharaan berkala. Sehingga dibutuhkan suatu teknologi lain untuk mereduksi biaya pemeliharaan kolam. Inovasi teknologi yang dilakukan berupa penggantian material kerangka besi menjadi kerangka bambu. Teknologi bioflok kerangka bambu yang diterapkan pada kegiatan pengabdian ini bertujuan untuk mereduksi biaya pemeliharaan budidaya udang vanami di kelompok nelayan Loang Ipon Desa Pijot.

\section{ANALISIS PERMASALAHAN}

Saat ini kelompok nelayan Loang Ipon Desa Pijot mulai menerapkan inovasi kolam terpal untuk budidaya udang vanami. Kelompok ini sudah memiliki 10 unit kolam terpal dengan kerangka besi. Penerapan inovasi ini sudah dilakukan selama \pm 1 tahun. Dari hasil lapangan, metode ini dapat mereduksi biaya budidaya udang jika dibandingkan dengan metode konvensional. Namun, metode ini memilki kelemahan yaitu mudah terjadi korosi (Gambar 1). Sifat korosif dapat menurunkan kekuatan mekanik besi karena terjadinya keropos. Sehingga kerangka ini perlu dilakukan perawatan berkala untuk mencegah korosi.

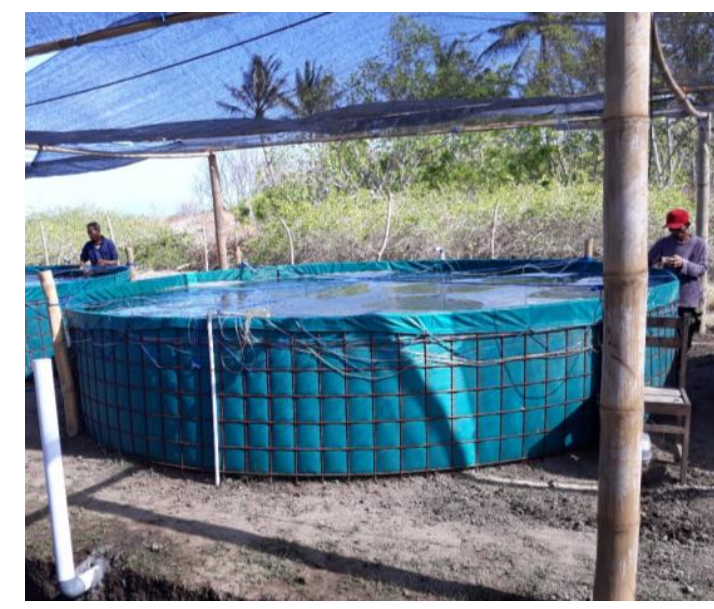

Gambar 1. Kolam terpal berbasis kerangka besi

Perawatan secara berkala pada besi idealnya dilakukan setiap 3 periode panen. Besi harus dilapisi kembali dengan cat yang baru. Proses pemeliharaan ini membutuhkan biaya \pm 1 juta setiap 3 periode perawatan untuk satu kolam. Oleh karena itu, biaya perawatan juga menjadi masalah yang dihadapi kelompok masyarakat ini.

\section{SOLUSI YANG DITAWARKAN}

Ketersediaan bambu diwilayah lombok cukup melimpah, salah satunya diwilayah senaru dengan luas lahan $225,7 \mathrm{Ha}$ rata-rata menghasilkan bambu mencapai 74,3 batang/ $\mathrm{Ha}$ (Husnul, et al, 2018). Selain itu, limbah bambu sisa proses pembangunan gedung-gedung juga cukup melimpah. Oleh karena itu, ketersediaan bambu yang melimpah ini dimanfaatkan sebagai bahan utama dalam pembuatan kolam terpal. Adapun Sifat fisis dan mekanis dari bambu ini menjadi dasar penggunaan bambu sebagai kerangka kolam terpal. Adapun sifat-sifat ini dipengaruhi oleh jenis bambu, umur bambu, tempat tumbuh, dan posisi dalam batang. Kekuatan lentur, tekan, dan tarik dinding bagian luar bambu lebih besar daripada bagian dalam (Sharma dan Mehra, 1970). Bambu yang digunakan untuk kolam terpal ini yaitu bambu andong (gigantochlao pseudoarundinacea). Bambu andong memiliki nilai MOR $1.032-1.835 \mathrm{~kg} / \mathrm{cm} 2$, MOE sebesar 96.616 - 
$121.395 \mathrm{~kg} / \mathrm{cm} 2$ dan tekan sejajar serat sebesar $562-631 \mathrm{~kg} / \mathrm{cm} 2$ (idris et al, 1980). Sehingga dapat menggantikan fungsi besi sebagai kerangka kolam terpal. Adapun beberapa tahapan yang dilakukan dalam pembuatan kolam terpal kerangka bambu yaitu:

\section{Desain Kolam Terpal}

Pembuatan kolam terpal kerangka bambu menggunakan desain yang sama dengan kolam terpal kerangka besi yang sudah diterapkan kelompok nelayan Loang Ipon. Adapaun desain ini harus memperhatikan beberapa hal seperti kontrol ketinggian air, pipa pembuangan air, dan pipa air masuk. Jumlah air pada kolam tidak boleh melebihi $15,7 \mathrm{~m}^{3}$ agar air tidak melimpah. Pipa kontrol air dibuat menggunakan prinsip hukum hidrostatis. Prinsip ini diterapkan melalui konsep pipa berhubungan benbentuk huruf $\mathrm{U}$ (Gambar 2).

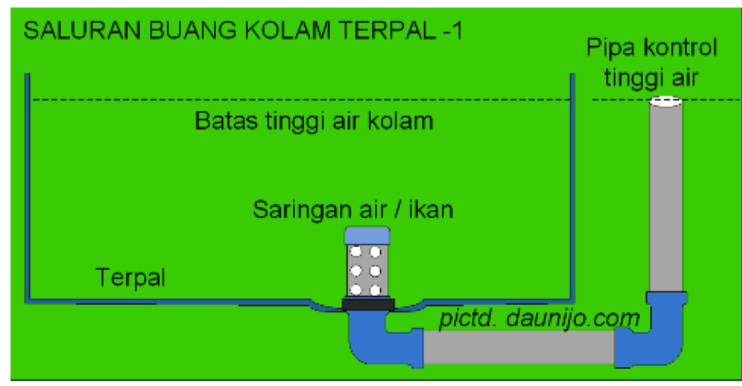

Gambar 2. Desain pipa kontrol air

\section{Persiapan}

Persiapan pembuatan kolam terpal berbasis bambu diawali dengan pemilihan lokasi. Lokasi yang dipilih harus dekat dengan air laut ataupun air payau dengan salinitas $30 \mathrm{ppt}$. Salah satu lokasi yang bersesuain dengan karakteristik ini yaitu daerah pesisir selayar Desa Pijot Kabupaten Lombok Timur. Didaerah ini terdapat kelompok petambak udang vanami yang sudah membudidayakan udang vanami dengan menggunakan kolam terpal kerangka besi.

Selain itu proses persiapan lain yaitu persiapan bambu. Bambu yang dimanfaatkan untuk kolam ini diperoleh dari sisa bambu pada proses pembangunan gedung. Bambu utuh dipotong dengan ukuran 1,5 m. Sebelum bambu diaplikasikan pada kolam, bambu direndam selama \pm 1 bulan di air asin (Gambar 3). Perendaman dilakukan untuk mencegah mengurangi kadar lignin pada bambu sehingga bambu tidak cepat rapuh oleh rayap. Setelah proses perendaman, bambu dijemur selama 1 minggu untuk mengurangi kadar air.

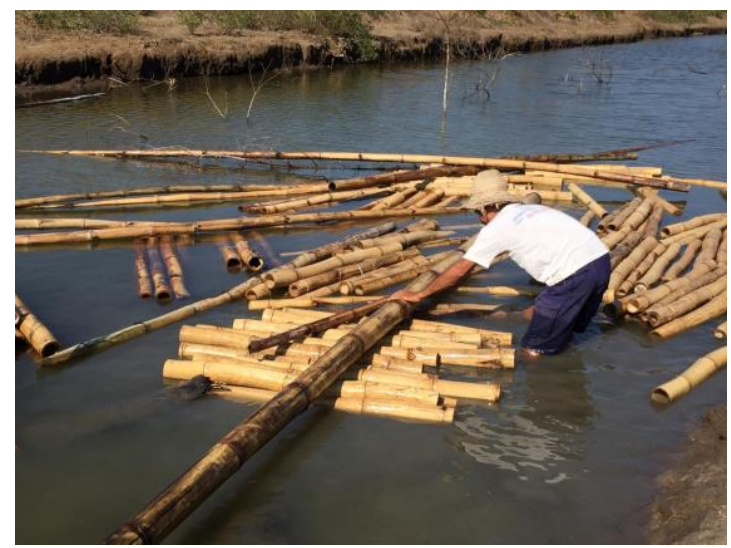

Gambar 3. Perendaman bambu di air laut atau payau 


\section{Pembuatan kolam}

Batang bambu yang telah melalui proses perendaman, siap dipasang pada pola yang sudah disiapkan. Pola dibuat dalam bentuk melingkar dengan diameter $5 \mathrm{~m}$. Pada garis keliling pola digali dengan kedalaman 0,3-0,5 m. Peletakan bambu diberi jarak sekitar 3- $5 \mathrm{~cm}$ (Gambar 4). Untuk menahan gaya dorong dari air, kekuatan bambu diperkuat dengan ikatan tali nilon pada bagian atas bambu. Sedangkan pada bagian bawah diperkuat dengan mengecor bambu.

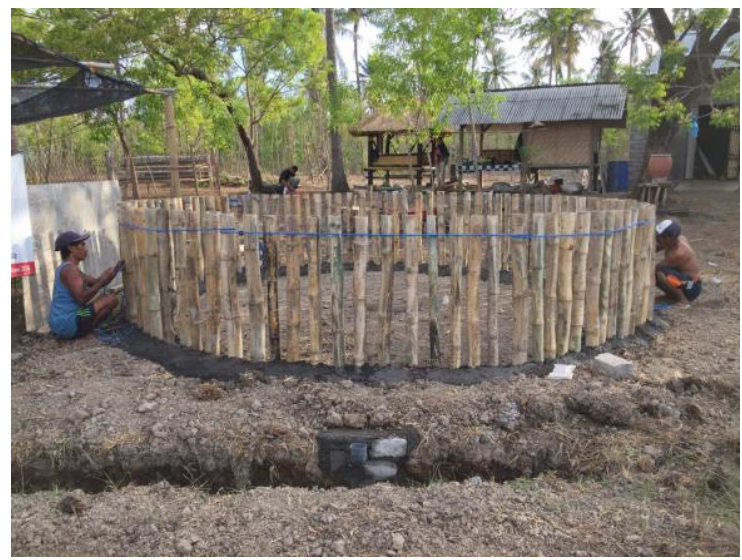

Gambar 4. Pemasangan bambu dan tali nilon

\section{Aplikasi kolam bioflok}

Pemasangan terpal dilakukan pada kerangka bambu yang sudah disiapkan. Air payau dengan kadar 30 ppt diisi sebanyak $\pm 15 \mathrm{~m}^{3}$. Kemudian berbagai stater kit untuk saluran udara (selang udara, tali nilon, dan blower) dipasang sesuai desain. Uji coba dilakukan selama \pm 2 minggu untuk memastikan kolam dapat digunakan.

\section{HASIL DAN PEMBAHASAN}

Pemberdayaan masyarakat pesisir Desa Pijot telah dilakukan dengan penerapan inovasi budidaya udang vanami menggunakan kolam bioflok kerangka bambu. Kolam kerangka bambu sudah dapat digunakan untuk budidaya udang. Desain kerangka kolam berbasis bambu memiliki kekuatan mekanik yang mampu menahan dorongan air dengan volume $15,7 \mathrm{~m}^{3}$ (Gambar 5). Kemampuan ini didukung oleh desain kerangka yang memperhatikan berbagai aspek gaya dorong air yang mungkin muncul. Untuk menahan gaya dorong air ini, kerangka didesain dengan peletakan antar bambu yang cukup rapat yaitu 3-5 cm, antar bambu pada bagian atas dijahit dengan tali nilon, dan setiap bambu ditanam sekitar 30$50 \mathrm{~cm}$. Analisis hasil pemakain kolam selama satu tahun menunjukkan bahwa ujung bambu yang ditanam menahan dorongan air bagian bawah, penjahitan antar bambu juga menjadi hal penting untuk memperkuat menahan gaya dorong air bagian atas, sedangkan peletakan bambu dengan jarak yang rapat untuk menahan kekuatan air dari segala arah. Sehingga dengan desain ini, kolam dapat dimanfaatkan kelompok nelayan loang ipon dengan daya tampung udang 30005000 ekor bibit untuk satu periode panen. Tiap periode panen, udang yang dihasilkan mencapai $30-50 \mathrm{~kg}$ per tiga bulan. 


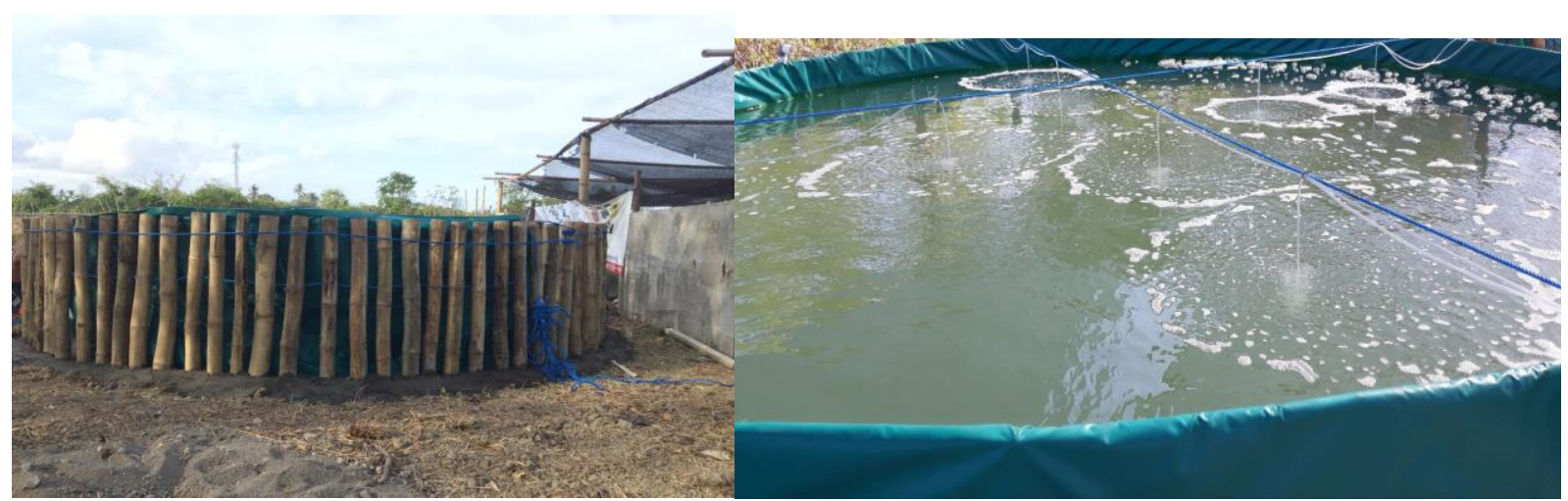

Gambar 5. Kolam terpal kerangka bambu

Adapun keutamaan lain yang diperoleh dengan menerapkan inovasi ini yaitu tidak terjadi korosi pada kerangka bambu. Lain hal nya dengan penerapan kolam kerangka besi yang terjadi korosi. Korosi pada kerangka dapat mengurangi kekuatan mekaniknya. Dengan kata lain korosi bisa menyebabkan besi keropos sehingga kolam rusak. Dari hasil pengamatan yang dilakukan, setelah pemakaian kerangka selama \pm 1 tahun besi mulai berkarat. Beda hal nya dengan bambu, setelah \pm 1 tahun pemakain tidak terjadi korosi. Korosi terjadi akibat reaksi antara $\mathrm{NaCl}$ dengan bahan besi. Bahan besi merupakan bahan yang memiliki karakteristif bersifat korosif ketika bereaksi dengan $\mathrm{NaCl}$.

Karakteristik korosif pada besi mengakibatkan perlunya penambahan biaya untuk pemeliharaan. Biasanya pemeliharaan yang dilakukan dengan mengecat kembali kerangka besi kolam. Sama hal nya dengan tambak konvensional yang ada. Selain biaya pembuatan yang mahal, biaya pemeliharaan tambak konvensional menjadi tantangan besar pagi pemilik tambak. Hal ini berbanding terbalik dengan kolam terpal kerangka bambu. Setelah pemakaian selama setahun, elastisitas tali nilon berkurang sehingga tali menjadi kendor. Ada 2 hal yang dapat dilakukan yaitu mengencangkan tali, atau mengganti tali nilon jika tidak memungkinkan untuk digunakan kembali. Selain itu, terkadang terdapat beberapa titik bambu yang mulai berbubuk akibat rayap. Peristiwa ini terjadi karena 2 faktor yaitu umur bambu yang masih muda atau kurang optimal saat tahapan perendaman bambu. Bambu yang rusak dapat diganti pada posisi yang rusak saja tanpa merusak yang lain. Sehingga pemanfaatan kolam kerangka bambu lebih murah 50\% dibandingkan kolam kerangka besi.

\section{KESIMPULAN}

Inovasi kolam bioflok kerangka bambu telah diterapkan pada kelompok nelayan Loang Ipon Desa Pijot Kabupaten Lombok Timur. Budidaya udang dengan teknologi ini menggunakan kolam diameter $5 \mathrm{~m}$. Satu tambak udang dapat menapung 3000- 5000 ekor bibit dengan hasil panen sekitar $30 \mathrm{~kg}-50 \mathrm{~kg}$. Biaya perawatan kolam kerangka bambu lebih murah 50\% dibandingkan kolam besi.

\section{UCAPAN TERIMA KASIH}

Pengabdian ini dilaksanakan dengan menggunakan sumber dana Bantuan Operasional Perguruan Tinggi no kontrak 1701/UN.18.L1/PP/2018.

\section{REFERENSI}

Amin, M. 2016. Screening of Cellulose-Degrading Bacteria Associated with Gastrointestinal Tract of Hybrid Abalone as Probiotic Candidates. International Journal Of Aquaculture. 6.

Amin, M., Bolch, C.J.S., Adams, M.B., Burke, C.M. 2017. Isolation of Alginate Lyaseproducing Bacteria and Screening for Their Potential Characteristics as Abalone Probionts. Aquaculture Research. 48, 5614-5623.

Amir, S., Setyono, B.D.H., Alim, S., Amin.M. 2018. Aplikasi Teknologi Bioflok Pada Budidaya Udang Vanami (Litopenaeus Vannamei). Prosiding PKM-CSR. Vol.1.

Gunadi, S. 2002. Teknologi Pemanfaatan Lahan Marginal Kawasan Pesisir. Jurnal Teknologi Lingkungan Vol. 3 No. 3. p: 232-236. 
Hotimah, Husnul., Latifah, Sitti., Indriyanto. 2018. Identifikasi jenis dan Pendugaan Potensi HHBK Bambu (Bambusa sp) di KHDTK Senaru, Kabupaten Lombok Utara. Jurnal HHBK.

Idris, A. A.; Anita F.; Purwito. 1980. Penelitian Bambu untuk Bahan Bangunan. Pusat Penelitian dan Pengembangan Pemukiman, Bandumg

Khoirunnas. 2011. Nilai Ekonomi dan Identifikasi Usahatani Lahan Pasir Pantai. http://geoenviron.blogspot.com/2011/05/.

Plomp, T. 1997. Development Research on/in Educational Development. Enschende : University of Twente.

Sharma, S.N.; Mehra, M.I. 1970. Variation of specific gravity and tangential shrinkage in the wall thickness of bamboo and its possible influence on trend of the shrinkage-moisture content characteristics. Indian Forest Bulletin 259,7.

Sulistiyani, A.T. 2004. Kemitraan dan Model-Model Pemberdayaan. Penerbit Gava Media. Yogyakarta. 216 hal.

Supono. 2017. Teknologi Produksi Udang. LPPM UNILA : Lampung.

Syarief, E. 2010. Pembangunan Kelautan dalam Konteks Pemberdayaan Masyarakat Pesisir. www.bappenas.go.id/index.php/download_ file/view/

Trisbiantoro, D., S. Oetami Madyowati, dan N. Trisyani. 2013. Model Pemberdayaan Masyarakat Kawasan Pesisir Kecamatan Watulimo, Kabupaten Trenggalek. Jurnal Mitra Ekonomi dan Manajemen Bisnis, Vol. 4 No. 1. p: 18-29. 